OPEN ACCESS

Edited by:

Anil Kumar Mishra, Institute of Nuclear Medicine, India

Reviewed by:

Puja Panwar Hazari,

Institute of Nuclear Medicine and

Allied Sciences, India

Maria Mathew D'Souza,

Institute of Nuclear Medicine and Allied Sciences, India

Baljinder Singh,

Postgraduate Institute of Medical Education and Research, India

${ }^{*}$ Correspondence: Joëlle Marcelle Gaschet joelle.gaschet@univ-nantes.fr

Specialty section: This article was submitted to Nuclear Medicine, a section of the journal

Frontiers in Medicine

Received: 30 July 2015 Accepted: 02 October 2015 Published: 19 October 2015

Citation:

Gorin J-B, Gouard S, Ménager J, Morgenstern A, Bruchertseifer $F$,

Faivre-Chauvet A, Guilloux Y, Chérel M, Davodeau F and Gaschet J

(2015) Alpha particles induce autophagy in multiple myeloma cells.

Front. Med. 2:74.

doi: 10.3389/fmed.2015.00074

\section{Alpha particles induce autophagy in multiple myeloma cells}

\author{
Jean-Baptiste Gorin 1,2,3, Sébastien Gouard1,2,3 , Jérémie Ménager ${ }^{1,2,3}$, Alfred Morgenstern ${ }^{4}$, \\ Frank Bruchertseifer ${ }^{4}$, Alain Faivre-Chauvet ${ }^{1,2,3,5}$, Yannick Guilloux ${ }^{1,2,3}$, Michel Chérel ${ }^{1,2,3,6}$, \\ François Davodeau ${ }^{1,2,3}$ and Joëlle Gaschet ${ }^{1,2,3 *}$ \\ 'CRCNA - UMR 892 INSERM, Nantes, France, ${ }^{2} 6299$ CNRS, Nantes, France, ${ }^{3}$ Université de Nantes, Nantes, France, \\ ${ }^{4}$ Institute for Transuranium Elements, Karlsruhe, Germany, ${ }^{5}$ Nuclear Medicine Department, CHU Nantes, Nantes, France, \\ ${ }^{6}$ Institut de Cancérologie de l'Ouest, Saint-Herblain, France
}

Objectives: Radiation emitted by the radionuclides in radioimmunotherapy (RIT) approaches induce direct killing of the targeted cells as well as indirect killing through the bystander effect. Our research group is dedicated to the development of $\alpha$-RIT, i.e., RIT using $\alpha$-particles especially for the treatment of multiple myeloma (MM). $\gamma$-irradiation and $\beta$-irradiation have been shown to trigger apoptosis in tumor cells. Cell death mode induced by ${ }^{213} \mathrm{Bi} \alpha$-irradiation appears more controversial. We therefore decided to investigate the effects of ${ }^{213} \mathrm{Bi}$ on $\mathrm{MM}$ cell radiobiology, notably cell death mechanisms as well as tumor cell immunogenicity after irradiation.

Methods: Murine 5T33 and human LP-1 MM cell lines were used to study the effects of such $\alpha$-particles. We first examined the effects of ${ }^{213} \mathrm{Bi}$ on proliferation rate, double-strand DNA breaks, cell cycle, and cell death. Then, we investigated autophagy after ${ }^{213} \mathrm{Bi}$ irradiation. Finally, a coculture of dendritic cells (DCs) with irradiated tumor cells or their culture media was performed to test whether it would induce DC activation.

Results: We showed that ${ }^{213} \mathrm{Bi}$ induces DNA double-strand breaks, cell cycle arrest, and autophagy in both cell lines, but we detected only slight levels of early apoptosis within the $120 \mathrm{~h}$ following irradiation in 5 T33 and LP-1. Inhibition of autophagy prevented ${ }^{213} \mathrm{Bi}$-induced inhibition of proliferation in LP-1 suggesting that this mechanism is involved in cell death after irradiation. We then assessed the immunogenicity of irradiated cells and found that irradiated LP-1 can activate DC through the secretion of soluble factor(s); however, no increase in membrane or extracellular expression of danger-associated molecular patterns was observed after irradiation.

Conclusion: This study demonstrates that ${ }^{213} \mathrm{Bi}$ induces mainly necrosis in MM cells, low levels of apoptosis, and autophagy that might be involved in tumor cell death.

Keywords: bismuth-213, multiple myeloma, radiobiology, autophagy, immunogenicity, ionizing radiation 


\section{INTRODUCTION}

Ionizing radiation (IR) is widely used in the treatment of cancer. External beam radiation therapy (EBRT) using X- or $\gamma$-rays is a primary treatment for a wide range of localized cancer, brachytherapy is commonly used as an effective treatment for cervical, prostate, breast, and skin cancer, and radioimmunotherapy (RIT) using $\beta$-emitters has proved its efficacy for the treatment of refractory non-Hodgkin lymphoma $(1,2)$.

New trials are now assessing the efficacy of $\alpha$-particle emitters in non-targeted or targeted therapies against hematological or solid cancers (3). Indeed, the physical and biological characteristics of those radioisotopes make them attractive candidates for the treatment of disseminated or residual cancers. $\alpha$-particles exhibit a high linear energy transfer (LET) $(\sim 100 \mathrm{keV} / \mu \mathrm{m})$ with a short range of 50-90 $\mu \mathrm{m}$ into the tissues combined with a high energy of 5-9 MeV. In addition, energy deposition along their path follows a Bragg peak, resulting in an increased LET at the end of the track and therefore an increased cytotoxicity. Like other high LET particles, $\alpha$-emitters induce complex clusters of DNA damages including DNA double-strand breaks (DSBs) which lead to a cell cycle arrest that is more marked than with $\gamma$-rays (4). Cell nucleus traversal with one to three $\alpha$-particles is sufficient to cause tumor cell death when 1000-5000 $\beta$-emitters would be required (5). Furthermore, radiobiological effects associated with $\alpha$-radionuclides are largely independent of dose rate, oxygenation, and cell proliferation (6). A few studies have investigated the cell death mechanisms in vitro and ex vivo after $\alpha$-irradiation and led to contrasting results. Some groups showed that cells undergo apoptosis following exposure to ${ }^{213} \mathrm{Bi}$ (7-9) while others observed cell death independent of apoptosis (10-12), therefore reinforcing the need for further investigation of such mechanisms.

Diverse $\alpha$-emitters have been used in the clinic so far, displaying short half-lives, like ${ }^{213} \mathrm{Bi},{ }^{211} \mathrm{At}$, and ${ }^{212} \mathrm{~Pb}$ as well as long-lived like ${ }^{223} \mathrm{Ra}$ and ${ }^{225} \mathrm{Ac}(3)$. Our group has done several in vitro and preclinical studies on multiple myeloma (MM) (12-16) using ${ }^{213} \mathrm{Bi}$ produced by ${ }^{225} \mathrm{Ac} /{ }^{213} \mathrm{Bi}$ radionuclide generators. Therefore, we thought to further investigate the impact of this $\alpha$-emitter on the radiobiology of MM cells, especially cell death mechanisms.

Moreover, experiments using EBRT have shown that in addition to direct tumor cell killing, IR can generate specific immune responses directed against tumor cells. Besides creating a local inflammatory context, it has been demonstrated that irradiation can induce immunogenic cell death (ICD) of cancer cells along with the release of danger-associated molecular patterns (DAMPs) $(17,18)$. Inflammation, ICD, and DAMPs promote the recruitment of immune cells to the tumor site, such as dendritic cells (DCs), which can internalize dying tumor cells. Then crosspresentation of tumor antigens by activated DCs primes antitumor T-cell response (19). Recently, we and others have shown that $\alpha$-particle emitters ${ }^{213} \mathrm{Bi}$ or ${ }^{224} \mathrm{Ra}$ can induce similar ICD of tumor cells (20-22) in combination with Hsp70 and HMGB-1 release, leading to efficient T-cell-dependent antitumor response $(20,21)$.

The aim of this study was to investigate the radiobiological effects, in particular cell death mechanisms, of ${ }^{213} \mathrm{Bi}$ on $\mathrm{MM}$ cells and to assess if irradiation of these tumor cells can lead to immune cell activation. Murine 5T33 and human LP-1 MM cell lines were used; we showed that ${ }^{213} \mathrm{Bi}$ induces inhibition of proliferation, DSBs, cell cycle arrest, and autophagy in both cell lines. Inhibition of autophagy prevented ${ }^{213} \mathrm{Bi}$-induced inhibition of proliferation in LP-1, suggesting that autophagy is one of the tumor cell death mechanisms after $\alpha$-irradiation. We then evaluated the immunogenicity of irradiated cells and found that irradiated LP-1 can activate DCs through the secretion of soluble factor(s).

\section{MATERIALS AND METHODS}

\section{Cell Culture, ${ }^{213} \mathrm{Bi}$-Irradiation, and Pharmacological Treatment}

5T33 (provided by Dr. Radl, TNO Institute, Leiden, Netherlands) and LP-1 cells (DSMZ: ACC 41) were maintained in RPMI 1640 (Gibco) supplemented with 10\% FCS, 2 mM glutamine (Gibco), $100 \mathrm{U} / \mathrm{mL}$ penicillin, and $100 \mu \mathrm{g} / \mathrm{mL}$ streptomycin (Gibco) at $37^{\circ} \mathrm{C}$ and $5 \% \mathrm{CO}_{2}$.

At least $2 \mathrm{~h}$ prior to irradiation, the cells were plated at $8 \times 10^{5}$ cells $/ \mathrm{mL}$ in fresh culture medium. A solution containing ${ }^{213} \mathrm{Bi}$ diluted in culture medium was then added to the cells. Thus, a final concentration of $4 \times 10^{5}$ cells $/ \mathrm{mL}$ was obtained in the presence of the desired activity of ${ }^{213} \mathrm{Bi}$.

For autophagy inhibition, cells were treated with $1.25 \mathrm{mM}$ 3-methyladenine (3-MA) (Sigma).

\section{Preparation of ${ }^{213} \mathrm{Bi}-\mathrm{BSA}$}

Cyclohexyl diethylene triamine penta-acetic acid (CHX-A" DTPA; Macrocyclics) was conjugated to BSA (Sigma) and controlled by indium labeling. For labeling with ${ }^{213} \mathrm{Bi}$, conjugated $\mathrm{BSA}$ was incubated with ${ }^{213} \mathrm{Bi}$ eluted from a ${ }^{225} \mathrm{Ac} /{ }^{213} \mathrm{Bi}$ generator (Institute for Transuranium Elements, Karlsruhe, Germany) for $10 \mathrm{~min}$ at $37^{\circ} \mathrm{C}$ in $0.4 \mathrm{M}$ ammonium acetate $(\mathrm{pH}, 5.3)$. The resulting ${ }^{213} \mathrm{Bi}-\mathrm{BSA}$ conjugate was purified from unbound ${ }^{213} \mathrm{Bi}$ by size exclusion chromatography using a PD-10 column (GE Healthcare).

\section{${ }^{3} \mathrm{H}$-Thymidine Incorporation Assay}

Approximately $16 \mathrm{~h}$ after ${ }^{213} \mathrm{Bi}$-irradiation, cells were plated in quadruplicates at $4 \times 10^{5}$ cells $/ \mathrm{mL}$ in $100 \mu \mathrm{L}$ in 96 -well flatbottom microtiter plates and incubated at $37^{\circ} \mathrm{C}$. Forty-two hours after irradiation, $10 \mu \mathrm{L}$ of ${ }^{3} \mathrm{H}$-thymidine $(925 \mathrm{kBq} / \mathrm{mL}$; Perkin Elmer) was added to each well and incubated at $37^{\circ} \mathrm{C}$. Six hours later (i.e., $48 \mathrm{~h}$ after irradiation), cells were harvested (Harvester 96 - Tomtec) on glass fiber Filtermat A (Perkin Elmer). Radioactive emission was amplified with Betaplate Scint (Perkin Elmer) and read using 1450 Microbeta Plus counter (Wallac). Results are expressed as quadruplicate mean \pm SD.

\section{Colony-Forming Assay}

Sixteen hours after irradiation, cells were plated in 96-well U-bottom microtiter plates at densities of 30, 10, 1, and 0.3 cells per well and cultured $2-3$ weeks at $37^{\circ} \mathrm{C}, 5 \% \mathrm{CO}_{2}$. Growth frequency was then calculated using Poisson distribution. 


\section{$\gamma \mathrm{H} 2 \mathrm{AX}$ Staining}

5T33 and LP-1 cells were fixed with 2\% PFA (EMS, Washington, PA, USA) and permeabilized with methanol in PBS-0.5\% BSA. $\gamma \mathrm{H} 2 \mathrm{AX}$ staining was performed with $\mathrm{PE}-\gamma \mathrm{H} 2 \mathrm{AX}$ antibody (BD Pharmingen) for $1 \mathrm{~h}$ at $4^{\circ} \mathrm{C}$. After two washes with PBS-0.5\% BSA and once with PBS, analysis of at least 10,000 events was performed using a BD FACScalibur flow cytometer and FlowJo software.

\section{Cell Cycle Analysis}

Cells were harvested, centrifuged, and resuspended in $200 \mu \mathrm{L}$ PBS. LP-1 and 5T33 were fixed by adding $1 \mathrm{~mL}$ of cold ethanol or methanol, respectively, for at least $10 \mathrm{~min}$ at $4^{\circ} \mathrm{C}$. Cells were then stained with propidium iodide as described previously (13) and at least 10,000 events were analyzed using a BD FACScalibur flow cytometer and FlowJo software.

\section{Annexin V and 7-AAD Staining}

Staining was performed according to manufacturer's instructions (BD Annexin V-PE Apoptosis detection kit). Briefly, $10^{5}$ cells were stained with $5 \mu \mathrm{L}$ Annexin $\mathrm{V}$-PE and/or 7-AAD for $15 \mathrm{~min}$ at room temperature in the dark. At least 10,000 events were analyzed using BD FACScalibur flow cytometer and FlowJo software.

\section{Western Blotting}

Cells were lysed in 1\% Triton X-100 lysis buffer containing protease inhibitors $(5 \mu \mathrm{g} / \mathrm{mL}$ aprotinin, $5 \mu \mathrm{g} / \mathrm{mL}$ leupeptin, and $4 \mathrm{mM}$ Pefablock $^{\circledR}$ ) for 15 min on ice. Cell debris were pelleted at $11,000 \times g$ for $20 \mathrm{~min}$ at $4^{\circ} \mathrm{C}$, and protein concentrations were determined by BCA reagent (Interchim). Proteins were separated by SDS-PAGE in a $15 \%$ acrylamide gel and transferred onto PVDF membranes. Blots were incubated $1 \mathrm{~h}$ in blocking buffer (TBS, $0.1 \%$ Tween 20, and 5\% milk) before incubation for $2 \mathrm{~h}$ with primary antibodies either rabbit anti-LC3B antibody $(1 \mu \mathrm{g} /$ $\mathrm{mL}$; Sigma) that recognizes both LC3B-I and LC3B-II forms or goat anti-actin (C-11, $50 \mathrm{ng} / \mathrm{mL}$; Santa Cruz, CA, USA). Blots were then incubated $1 \mathrm{~h}$ with the appropriate HRP-conjugated secondary antibody and processed to detect electrochemiluminescence (Roche). The signal was acquired with the Fusion FX7 camera and its intensity determined using Bio-1D software (Vilber Lourmat).

\section{Transmission Electron Microscopy}

Non-irradiated and ${ }^{213} \mathrm{Bi}$-irradiated 5T33 and LP-1 cells were fixed in cacodylate buffered $4 \%$ glutaraldehyde for $15 \mathrm{~min}$ at $4^{\circ} \mathrm{C}$, washed, and post-fixed in cacodylate buffered $2 \%$ osmium tetroxide for $20 \mathrm{~min}$ at $4^{\circ} \mathrm{C}$. Samples were dehydrated in successive dilutions of ethanol and embedded overnight in Epon at $37^{\circ} \mathrm{C}$ and for two other days at $55^{\circ} \mathrm{C}$. Sections ( $80 \mathrm{~nm}$ thick) were cut with an Ultracut E ultramicrotome (Reichert-Jung), mounted on copper grids, stained with uranyl acetate, and observed on a JEOL 1010 TEM.

\section{DCs Production}

Human DCs were obtained by differentiation of human monocytes. Monocytes were purified from PBMCs by counterflow centrifugal elutriation and cultured 5 days in RPMI supplemented with $2 \%$ human albumin, $2 \mathrm{mM}$ glutamine, $100 \mathrm{U} / \mathrm{mL}$ penicillin, $100 \mu \mathrm{g} / \mathrm{mL}$ streptomycin, GM-CSF $1000 \mathrm{IU} / \mathrm{mL}$ (CellGro), and IL-4 $200 \mathrm{IU} / \mathrm{mL}$ (BruCells). Mouse DCs were obtained by differentiation of bone marrow from $\mathrm{C} 57 \mathrm{Bl} / 6$ thigh bone as described previously (20).

\section{Coculture Assays}

For DC coculture assay with tumor cells, five million ${ }^{213} \mathrm{Bi}$-treated tumor cells (LP-1 or $5 \mathrm{~T} 33$ ) or non-irradiated tumor cells were centrifuged $48 \mathrm{~h}$ after irradiation. Tumor cell pellets were resuspended in $1 \mathrm{~mL}$ fresh medium and added to one million DCs (human or mouse) in a total volume of $2 \mathrm{~mL}$ and plated in six-well dishes. Twenty-four hours after coculture at $37^{\circ} \mathrm{C}, \mathrm{DC}$ maturation was analyzed by immunofluorescence phenotyping.

For DC coculture assay with tumor cell supernatant, $48 \mathrm{~h}$ after irradiation, $1 \mathrm{~mL}$ of tumor cell supernatant, obtained after centrifugation of five million irradiated or non-irradiated tumor cells (LP-1 or 5T33), was added to one million DCs (human or mouse) in a total volume of $2 \mathrm{~mL}$ and plated in 12-well plates.

\section{Immunofluorescence Analysis}

Cells were washed once in $0.1 \%$ BSA-PBS and then stained for $1 \mathrm{~h}$ at $4^{\circ} \mathrm{C}$ with primary antibody. When secondary antibody was needed, cells were washed three times in $0.1 \%$ BSA-PBS before incubation with secondary antibody. After staining, cells were washed twice in $0.1 \%$ BSA-PBS and once in PBS before acquisition in flow cytometer. The following antibodies and their respective control isotypes were used in this study: PE anti-human CD80 (L307.4; BD), APC anti-human CD83 (HB15e; BD), APC antihuman CD86 (2331 FUN-1; BD), and PE anti-HLA-DR (G46.6; $\mathrm{BD})$. All immunofluorescence analyses were performed using a FACScalibur flow cytometer (BD Pharmingen) and analyzed with FlowJo software.

\section{RESULTS}

\section{${ }^{213} \mathrm{Bi}$ Irradiation Hampers Cell Proliferation}

5T33 cells and LP-1 cells were irradiated with increasing activities of ${ }^{213} \mathrm{Bi}$ and their proliferation rate was assessed $48 \mathrm{~h}$ later by ${ }^{3} \mathrm{H}$-thymidine incorporation assay. Results show a dosedependent inhibition of ${ }^{3} \mathrm{H}$-thymidine incorporation attesting of a diminution of DNA synthesis and as a result a diminution of their proliferation ability (Figure 1). ${ }^{213} \mathrm{Bi}$ activities sufficient to cause at least $80 \%$ inhibition of proliferation for each cell line were then used for the rest of the study, respectively, $370 \mathrm{kBq} /$ $\mathrm{mL}$ for $5 \mathrm{~T} 33$ and $425 \mathrm{kBq} / \mathrm{mL}$ for LP-1. Such activities ensure a strong biological effect but remain low enough that the cells are not sterilized by irradiation.

\section{Inhibition of Proliferation is Correlated with Tumor Cell Death}

In order to determine to what extend the inhibition of proliferation had an impact on tumor cell survival, we performed colonyforming assays. This approach consists in seeding irradiated and non-irradiated cells in clonal conditions to measure the impact 

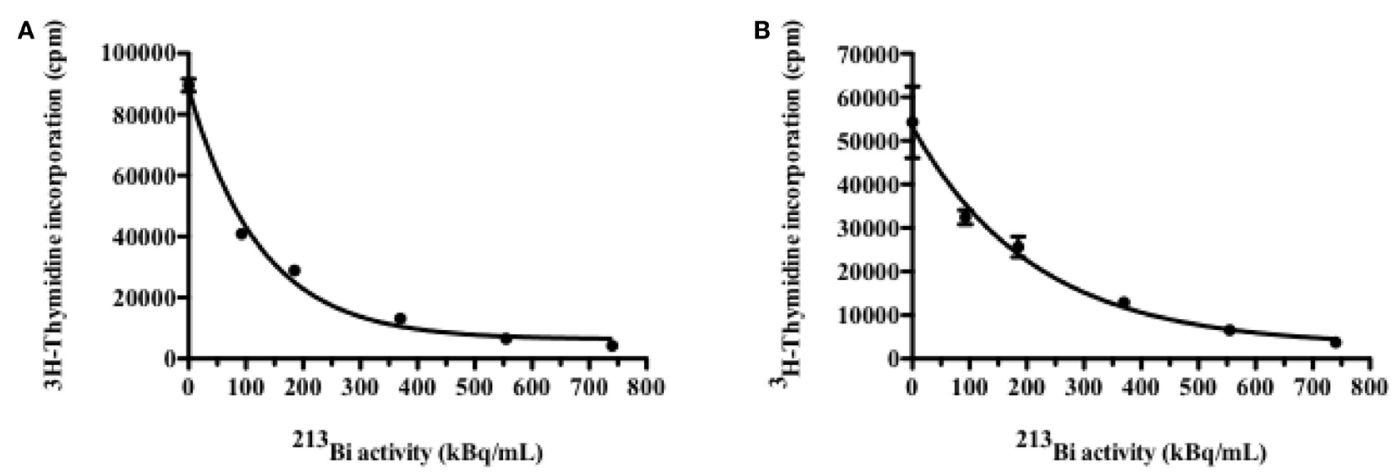

FIGURE 1 | Inhibition of cell proliferation by ${ }^{213} \mathbf{B i}$ irradiation. Proliferation of irradiated 5 T33 (A) and LP-1 (B) cells assessed $48 \mathrm{~h}$ after irradiation by incorporation of ${ }^{3} \mathrm{H}$-thymidine. Data are expressed as quadruplicate mean $\pm \mathrm{SD}$ and are representative of two independent experiments.

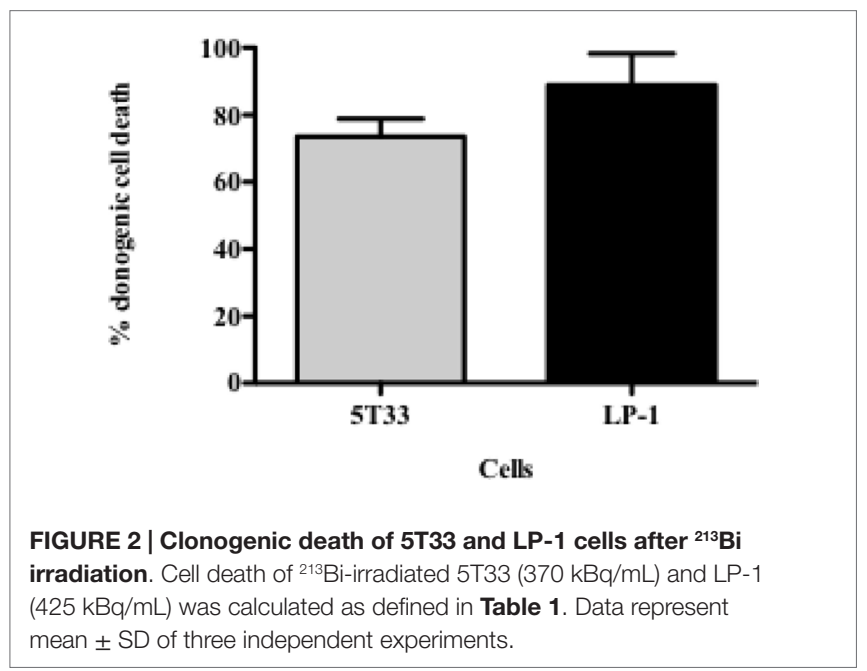

TABLE 1 | Colony-forming assay of 5 T33 and LP-1 cells after ${ }^{213} \mathrm{Bi}$ irradiation.

\begin{tabular}{llccc}
\hline Cells & Condition & Growth efficiency (\%) & Survival (\%) & Death (\%) \\
\hline \multirow{2}{*}{5 T33 } & Control & $22.4 \pm 6.0$ & 100 & 0 \\
& $370 \mathrm{kBq} / \mathrm{mL}$ & $5.8 \pm 1.8$ & $26.5 \pm 4.6$ & $73.5 \pm 4.6$ \\
LP-1 & Control & $40.2 \pm 31.6$ & 100 & 0 \\
& $425 \mathrm{kBq} / \mathrm{mL}$ & $6.4 \pm 6.7$ & $11.2 \pm 7.1$ & $88.8 \pm 7.1$ \\
\hline
\end{tabular}

Colony-forming assays were performed $16 \mathrm{~h}$ after irradiation with non-irradiated or ${ }^{213} \mathrm{Bi}$-irradiated 5 T33 $(370 \mathrm{kBq} / \mathrm{mL})$ and LP-1 $(425 \mathrm{kBq} / \mathrm{mL})$ cells to determine growth using Poisson distribution. Data represent mean $\pm S D$ of three independent experiments.

of ${ }^{213} \mathrm{Bi}$ irradiation on cell growth efficiency. We observed that clonogenic cell death after irradiation reached $73.5 \pm 4.6 \%$ for 5 T33 cells treated at $370 \mathrm{kBq} / \mathrm{mL}$ and $88.8 \pm 7 \%$ for LP- 1 treated at $425 \mathrm{kBq} / \mathrm{mL}$ (Figure 2; Table 1). This confirmed that blockade of 5T33 and LP-1 cell proliferation is indeed correlated to the same extent to tumor cell death induced on the long term after ${ }^{213} \mathrm{Bi}$ treatment.

\section{${ }^{213} \mathrm{Bi}$ Induces DNA DSBs in MM Cells}

Induction of DSBs in 5T33 and LP-1 cells was investigated after ${ }^{213} \mathrm{Bi}$ irradiation at $370 \mathrm{kBq} / \mathrm{mL}$ or $425 \mathrm{kBq} / \mathrm{mL}$, respectively (Figure 3). Irradiation appeared homogenous since for both cell lines, the entire cell population exhibited $\gamma \mathrm{H} 2 \mathrm{AX}$ staining (Figure 3). For both cell lines also, DSBs were detectable already 15 min after treatment and their amount increased following the same kinetic over time to reach a maximum at $2 \mathrm{~h}$. Then, phosphorylation of $\mathrm{H} 2 \mathrm{AX}$ histone decreased, as observed $3 \mathrm{~h}$ after irradiation.

\section{${ }^{213} \mathrm{Bi}$ Blocks Cell Cycle}

Cell cycle arrest can arise from DNA damages; therefore, the effect of ${ }^{213} \mathrm{Bi}$ on $5 \mathrm{~T} 33$ and LP-1 cell cycle at different time points following irradiation was then investigated (Figure 4). Accumulation in the $\mathrm{G} 2 / \mathrm{M}$ phase occurred quite rapidly after irradiation in both cell lines. In 5T33 cells (Figure 4A), cell cycle blockade was seen as soon as $6 \mathrm{~h}$ after irradiation with $370 \mathrm{kBq} /$ $\mathrm{mL}$ of ${ }^{213} \mathrm{Bi}$ and reached a maximum at $24 \mathrm{~h}$ with around $45 \%$ of the cells in the G2 phase. In LP-1 cells (Figure 4B), cell cycle blockade was slower, being noticeable $24 \mathrm{~h}$ after treatment with $425 \mathrm{kBq} / \mathrm{mL}$ and reaching a maximum at $36 \mathrm{~h}$ with almost $63 \%$ of the cells blocked in the G2 phase. These results demonstrate that $\alpha$-particles cause a blockade at the G2/M checkpoint with a kinetic that varies depending on the cell line.

\section{${ }^{213} \mathrm{Bi}$ Induces Necrosis in MM Cells}

Since 5T33 and LP-1 cells experience serious DSBs, are blocked in $\mathrm{G} 2$ phase, and stop proliferating after ${ }^{213} \mathrm{Bi}$ irradiation, experiments were conducted to determine the mechanisms that would eventually lead to cell death. Annexin V/7AAD staining was performed on the two MM cell lines at different time points after irradiation to investigate early apoptosis [Annexin $\mathrm{V}(+)$ cells] as well as late apoptosis and necrosis [Annexin V (+) 7AAD $(+)$ cells] (Figure 5). Non-irradiated MM cells were studied in parallel. Early apoptosis was barely detectable in any of the cell lines and was not observed immediately after irradiation but to a small extent at later time point, after $36 \mathrm{~h}$ for $5 \mathrm{~T} 33$ and $96 \mathrm{~h}$ for 

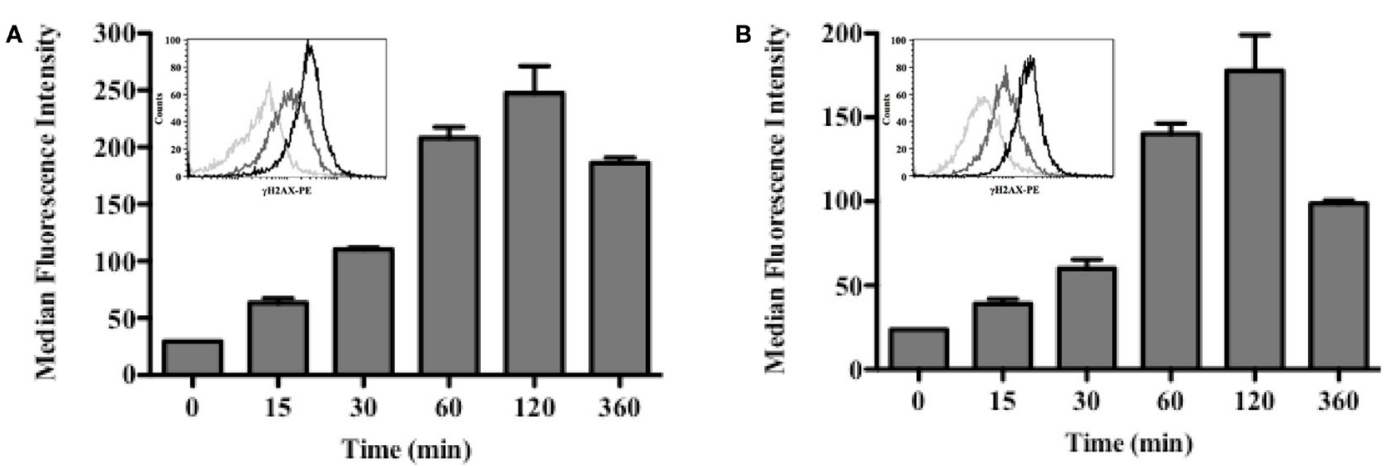

FIGURE 3 | DSBs are induced shortly after irradiation with ${ }^{213}$ Bi. $5 T 33$ (A) and LP-1 (B) cells were irradiated at 370 and $425 \mathrm{kBq} / \mathrm{mL}$, respectively. DSBs were analyzed at different time points after irradiation by flow cytometry using an anti- $\gamma \mathrm{H} 2 \mathrm{AX}$ mAb. Flow cytometry histograms illustrate homogeneous $\gamma \mathrm{H} 2 \mathrm{AX}$ staining for both cell lines: 0 min (light gray), 30 min (dark gray), and 120 min (black). Bar graphs represent median \pm SD of two independent experiments.
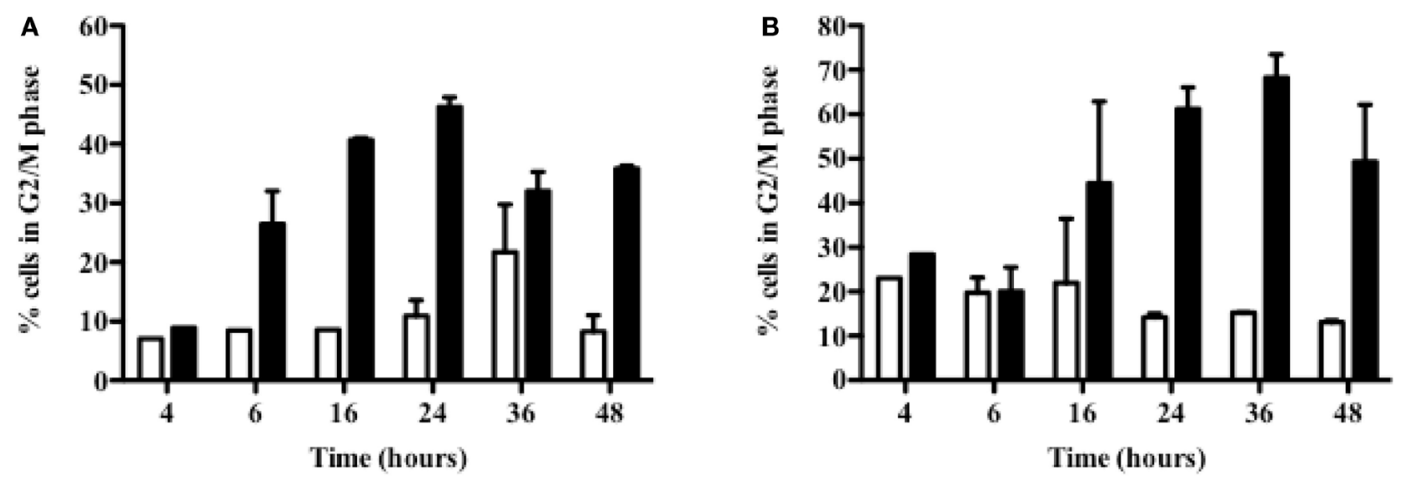

FIGURE 4 | Accumulation in G2 phase of ${ }^{213} \mathbf{B i}$-irradiated $\mathbf{5 T 3}$ and LP-1 cells. 5T33 (A) and LP-1 (B) cells were irradiated at 370 and $425 \mathrm{kBq} / \mathrm{mL}$, respectively. Then cell cycle analysis was performed at different time points after ${ }^{213} \mathrm{Bi}$ irradiation of the cells (black bars) and compared to control non-irradiated cells (white bars). Data represent mean \pm SD of two independent experiments.

LP-1. These data suggest that cell death occurs mainly through necrosis. This was confirmed by active caspase-3 detection and DNA fragmentation analysis that also showed small levels of early apoptosis (data not shown). In 5T33 cells, necrosis appeared at $36 \mathrm{~h}$ and reached a maximum at $96 \mathrm{~h}$ after irradiation at $370 \mathrm{kBq} /$ $\mathrm{mL}$ of ${ }^{213} \mathrm{Bi}$. In LP-1, necrosis seems to arise later and is strikingly increased at $96 \mathrm{~h}$ after irradiation at $425 \mathrm{kBq} / \mathrm{mL}$. Non-irradiated 5 T33 control cells kept dividing actively over the time of the experiment and despite splitting exhibited important cell death as observed after $96 \mathrm{~h}$ of culture.

\section{${ }^{213} \mathrm{Bi}$ Induces Autophagy in MM Cells}

Autophagy can be induced in cells as a response to a variety of stress factors, including IR-induced oxidative stress, and is characterized by an increased number of autophagosomes that exhibit a lipid bilayer membrane. At the molecular level, when autophagy is activated, the LC3-B protein is converted from the cytosolic LC3B-I form to the LC3B-II form recruited on the autophagosome membrane. Common methods to assess autophagy are Western blot of the LC3-B protein, TEM, and use of autophagy inhibitors.
Western blot assays on irradiated and non-irradiated MM cell lysates were analyzed by standardization of LC3B-II form to actin as mentioned by Mizushima and Yoshimori (23) and showed a strong induction of LC3B-I form conversion to the LC3B-II form after ${ }^{213} \mathrm{Bi}$ irradiation (Figure 6). Accumulation of the LC3B-II form of the LC3B protein was observed in 5 T33 cells at $24 \mathrm{~h}$, further increased at $36 \mathrm{~h}$, and remained stable until $72 \mathrm{~h}$ after irradiation at $370 \mathrm{kBq} / \mathrm{mL}$. In LP-1 cells, after a transient and early accumulation at $16 \mathrm{~h}, \mathrm{LC} 3 \mathrm{~B}-\mathrm{II}$ form decreased before raising again at $48 \mathrm{~h}$ and remained stable at $96 \mathrm{~h}$ after treatment with $425 \mathrm{kBq} / \mathrm{mL}$ of ${ }^{213} \mathrm{Bi}$. For both cell lines, non-irradiated cells did not exhibit major changes in LC3B-II form accumulation over the time of experiments (Figure 6). Moreover, the presence of autophagosomes in ${ }^{213} \mathrm{Bi}$-treated $5 \mathrm{~T} 33$ and LP-1 cells was confirmed by TEM analysis (Figure 7). Altogether, these results demonstrate that $\alpha$-particles induce autophagy in MM cells.

Autophagy has been described both as a cell survival and cell death mechanism depending on the stimuli, context, and/or cell lines studied. To assess the role of autophagy in our cell lines after irradiation with ${ }^{213} \mathrm{Bi}$, both proliferation and colony-forming assays 
A

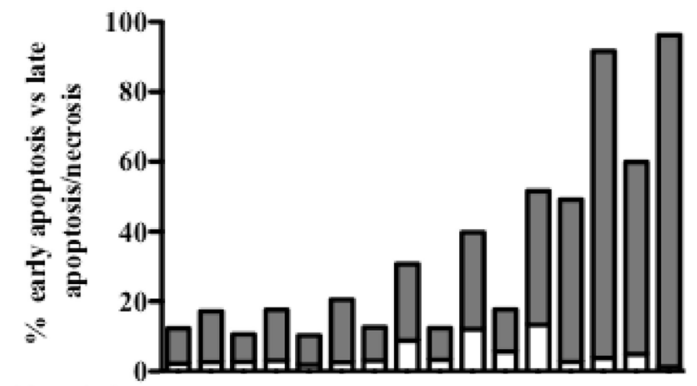

${ }^{213} \mathrm{Bi}$ irradiation

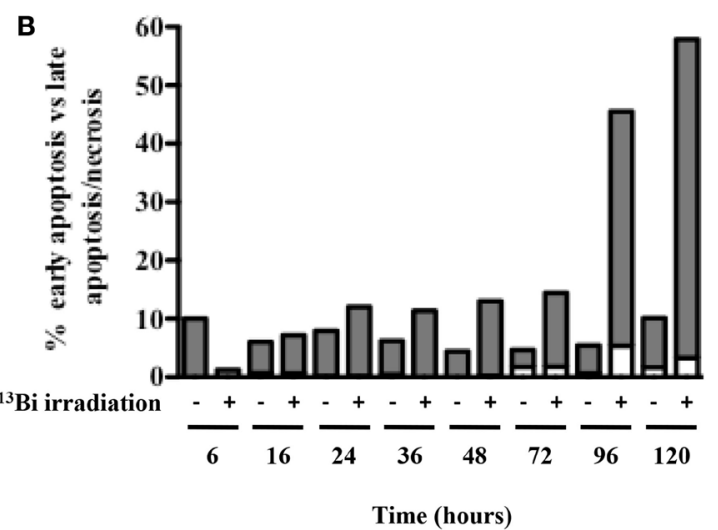

FIGURE 5 | Apoptosis and necrosis in MM cells after ${ }^{213} \mathrm{Bi}$ irradiation. Early apoptosis (white bars) and late apoptosis/necrosis (gray bars) were assessed at different time points after irradiation of $5 T 33$ cells $(\mathbf{A})$ at $370 \mathrm{kBq} / \mathrm{mL}$ and $\mathrm{LP}-1$ cells (B) at $425 \mathrm{kBq} / \mathrm{mL}$. Data are representative of two independent experiments.
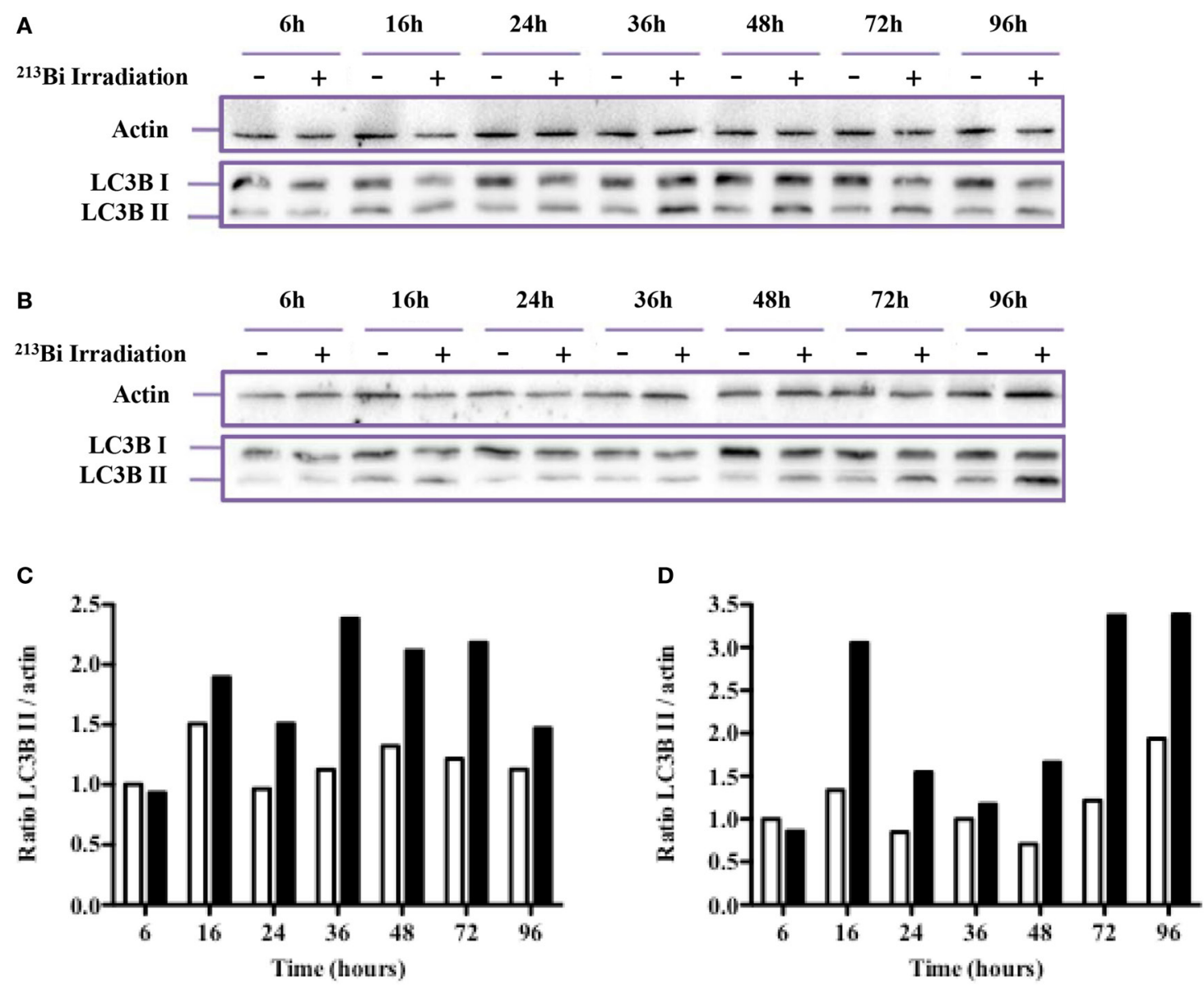

FIGURE 6 | ${ }^{213} \mathrm{Bi}$ irradiation induces autophagy in $\mathbf{5 T 3 3}$ and LP-1 cells. To analyze autophagy, Western blot analysis of LC3B I conversion to the LC3B || form was performed at different time points after irradiation in $5 T 33$ cells (A) at $370 \mathrm{kBq} / \mathrm{mL}$ and LP-1 cells (B) at $425 \mathrm{kBq} / \mathrm{mL}$. Densitometry analysis of the blots was performed to determine the LC3B II to actin ratios in control non-irradiated (white bars) and irradiated (black bars) 5 T33 (C) and LP-1 (D) cells. Data are representative of three independent experiments. 


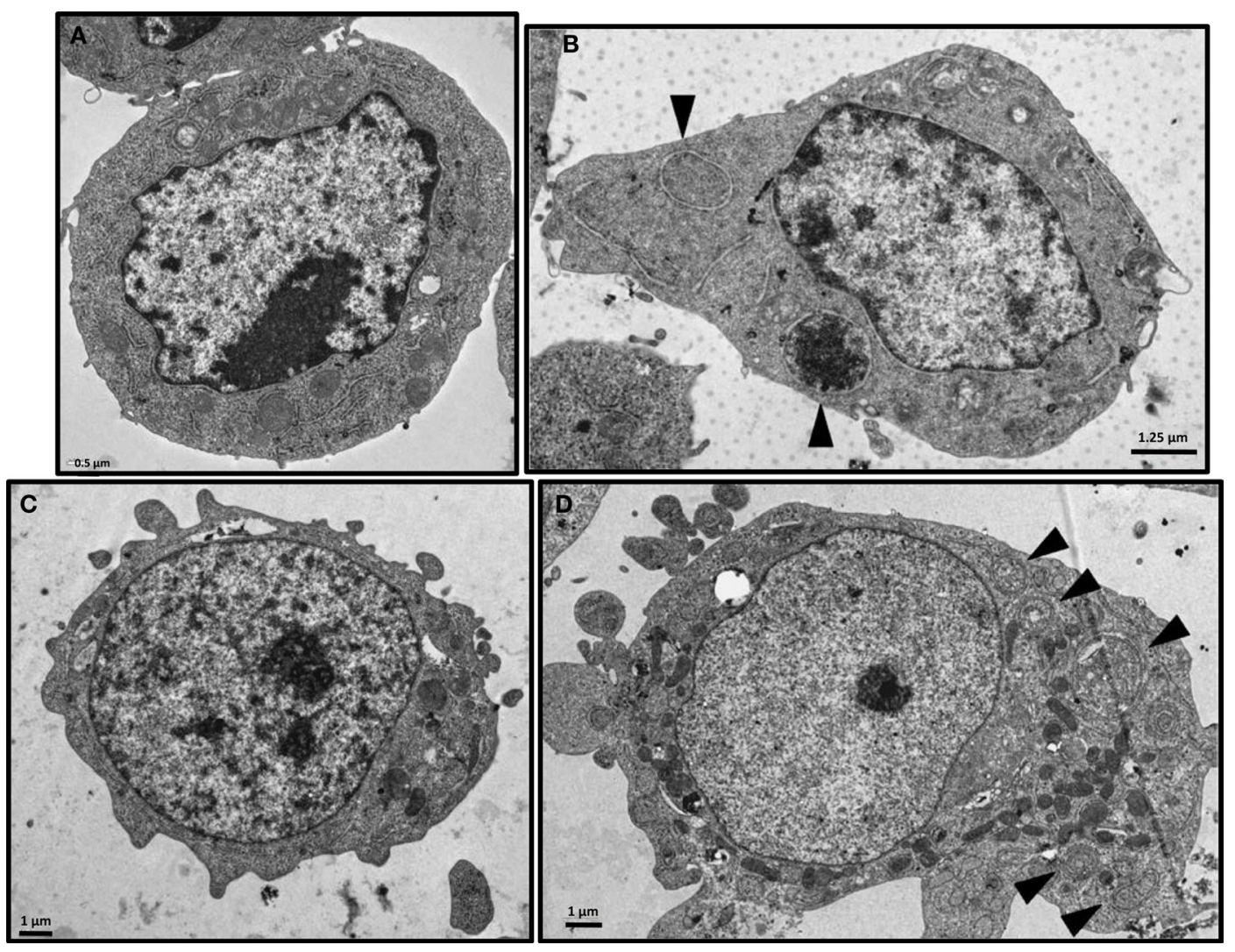

FIGURE 7 | Electron microscopy of ${ }^{213} \mathbf{B i}$-treated cells. Analysis was performed on 5 T33 cells: untreated $(\mathbf{A})$ or $48 \mathrm{~h}$ after irradiation with $370 \mathrm{kBq} / \mathrm{mL}{ }^{213} \mathrm{Bi}$ (B) and on LP-1 cells: untreated (C) or $72 \mathrm{~h}$ after irradiation with $425 \mathrm{kBq} / \mathrm{mL}{ }^{213} \mathrm{Bi}$ (D). Autophagic vacuoles presenting lipid bilayer membrane are indicated by arrows.

were conducted in the presence of an autophagy inhibitor - 3methyladenine (3-MA) - which inhibits more specifically class III phosphoinositide 3-kinase activity known to be essential for autophagy induction. In 5T33, at $1.25 \mathrm{mM}$ of 3-MA, the proliferation rate after ${ }^{213} \mathrm{Bi}$ treatment with or without inhibition of autophagy was quite similar (data not shown). However, for LP-1 cells, when autophagy was blocked by $3-\mathrm{MA}$, the proliferation rate after irradiation was affected. As shown in Figure 8A, the amount of 3-MA used in that experiment had no major effect on proliferation of non-irradiated LP-1 cells. As shown previously, treatment of LP-1 cells at $425 \mathrm{kBq} / \mathrm{mL}$ with ${ }^{213} \mathrm{Bi}$ induced around $90 \%$ decrease in proliferation rate. Then, when LP-1 cells were irradiated with ${ }^{213} \mathrm{Bi}$ in the presence of $3-\mathrm{MA}$, the cells appeared protected from irradiation and kept proliferating at least for $72 \mathrm{~h}$. These results raise the hypothesis that autophagy is involved, at least in part, as a cell death mechanism after treatment with ${ }^{213} \mathrm{Bi}$. Nevertheless, when clonogenic colony assays were performed on ${ }^{213} \mathrm{Bi}$-irradiated LP-1 in the presence of 3-MA, cell death occurred to the same extent with or without autophagic inhibition (Figure 8B).

\section{${ }^{213} \mathrm{Bi}$-Treated Tumor Cells Activate Dendritic Cells}

Besides its direct killing of tumor cells, IR has been shown to induce indirect killing via the immune system. To assess the immunogenicity of alpha-irradiated tumor cells, ${ }^{213} \mathrm{Bi}$-treated
LP-1 $(425 \mathrm{kBq} / \mathrm{mL})$ or their culture media have been cultured with human DCs. After 1 day of coculture, the DC expression of activation markers (CD80, CD83, CD86, and HLA-DR) was determined by flow cytometry. The culture media of irradiated LP-1 yielded a strong activation of DCs (Figure 9). However, such activation was not observed when DCs were cocultured directly with the irradiated cells alone (without their culture media) (Figure 9). Coculture with irradiated tumor cells plus their culture media did not result in further DC activation (data not shown). These data suggest that the factor(s) capable of activating DCs are secreted in the culture media after irradiation with ${ }^{213} \mathrm{Bi}$. Experiments performed with irradiated 5T33 cells and irradiated 5T33 cell supernatants showed quite similar results on murine DC activation.

To identify the potential factor(s), dosage of common DAMPs was performed on culture media of irradiated 5T33 and LP-1 at $370 \mathrm{kBq} / \mathrm{mL}$ or $425 \mathrm{kBq} / \mathrm{mL}$, respectively. No difference in release of HMGB1, Hsp70, or TNF $\alpha$ was observed after irradiation with ${ }^{213} \mathrm{Bi}$ (data not shown). The membrane expression of Hsp70, Hsp90, and calreticulin was also tested by flow cytometry; again, no difference was seen after $\alpha$-irradiation (data not shown).

\section{DISCUSSION}

In this study, we showed that ${ }^{213} \mathrm{Bi}$ irradiation of $\mathrm{MM}$ cells induced DSBs followed by a cell cycle arrest in G2/M phase and an increased 


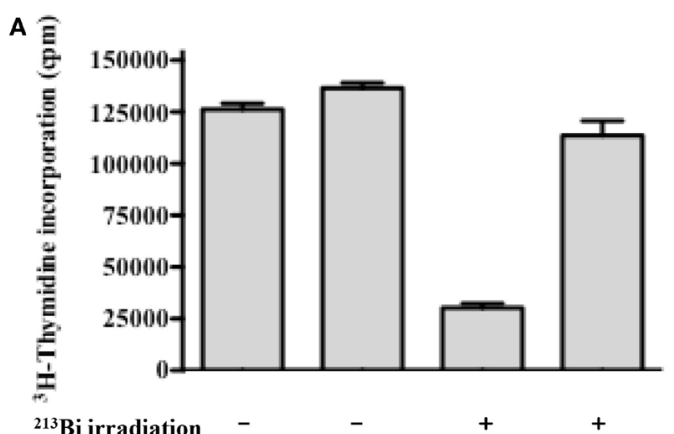

3-MA

B

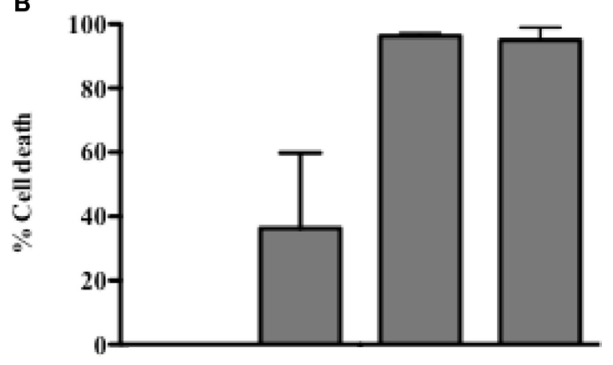

${ }^{213} \mathrm{Bi}$ irradiation

3-MA

FIGURE 8 | Inhibition of autophagy restores proliferation of LP-1 cells but do not impact clonogenic cell death. (A) Proliferation of irradiated or control LP-1 cells with or without autophagic inhibitor was assessed $72 \mathrm{~h}$ after irradiation by incorporation of ${ }^{3} \mathrm{H}$-thymidine. (B) Clonogenic cell death of untreated LP-1 or after ${ }^{213} \mathrm{Bi}$ irradiation with or without autophagic inhibitor. Data represent mean \pm SEM of two independent experiments.

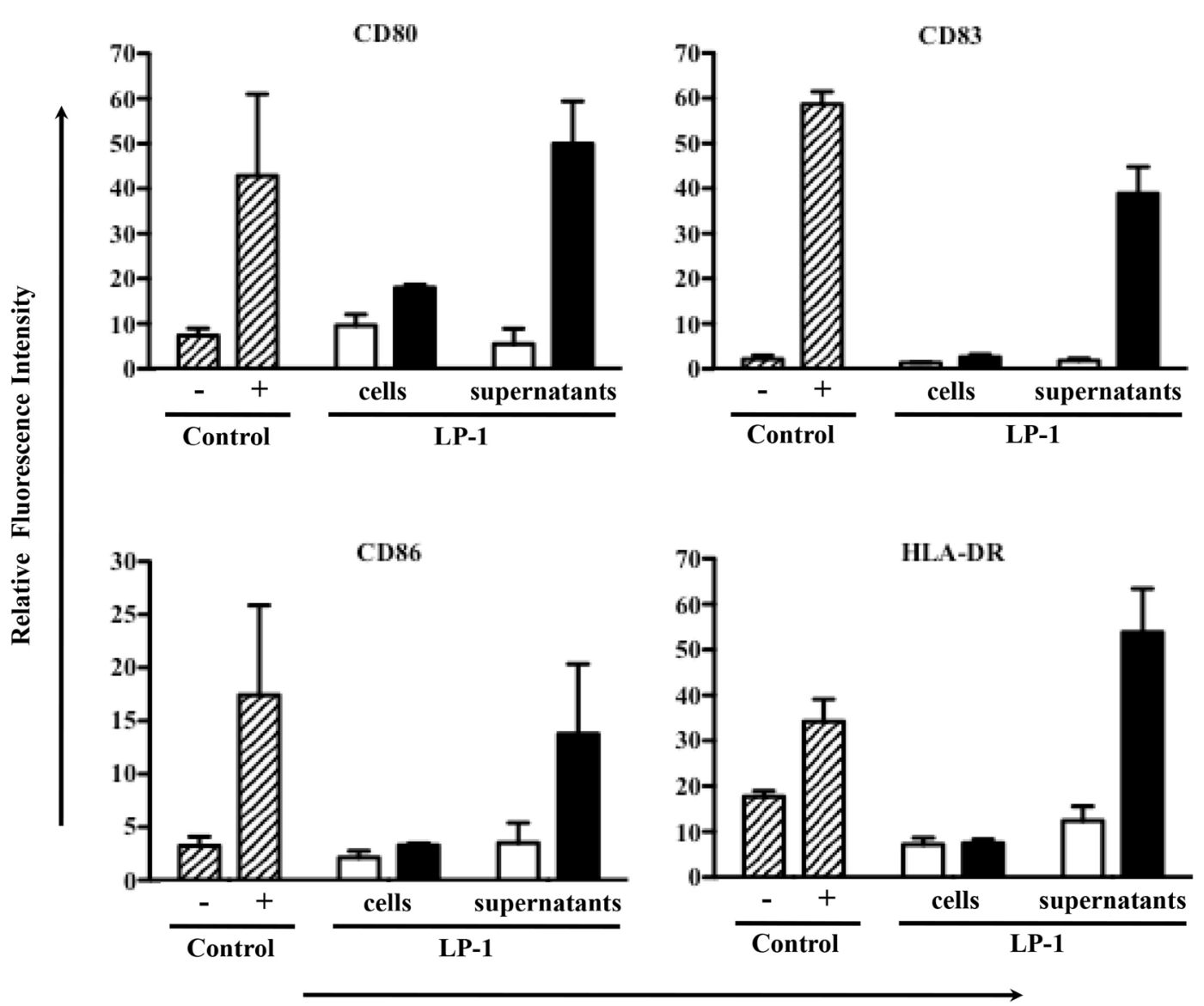

DC co-culture condition

FIGURE 9 | Effect of ${ }^{213} \mathbf{B i}$ irradiation on immune cells. DC cell activation markers were analyzed $24 \mathrm{~h}$ after coculture with ${ }^{213} \mathrm{Bi}$-treated (black bars) LP-1 cells or LP-1 supernatants as well as untreated (white bars) LP-1 cells or LP-1 supernatants. Control DCs (dashed bars) cocultured alone were used as negative control (-), whereas DCs cocultured with LPS and TNF $\alpha$ were used as positive control (+). Data represent means of ratio of fluorescence intensity \pm SEM of two independent experiments.

amount of LC3B-II protein, indicating a raise in autophagy. Mechanisms leading to the death of irradiated cells seem to implicate apoptosis, necrosis, and could also involve autophagy.
We used ${ }^{213} \mathrm{Bi}-\mathrm{BSA}$, a non-specific vector in order to perform a homogeneous irradiation of the cells. Irradiation was indeed homogenous as demonstrated by the $\gamma \mathrm{H} 2 \mathrm{AX}$ flow cytometry 
histograms, since $100 \%$ of cells exhibited DSBs with a maximum reached around $2 \mathrm{~h}$ after $\alpha$-irradiation (Figure 3). Following induction of DSBs by ${ }^{213} \mathrm{Bi}$ treatment, we observed a cell cycle blockade in the MM cells. IR is known to induce cell cycle arrest in G1 and G2 phase (24). However, cell cycle blockade in G1 is controlled by $\mathrm{p} 53$ and is therefore scarce in tumor cells. It has been shown that $\alpha$-emitters could also induce a G1 arrest in cells that present a functional p53 $(25,26)$. The fact that neither LP-1 nor 5T33 cells exhibit such blockade in G1 phase indicates that p53 is deficient in these cell lines. TP53 gene is actually mutated in LP-1 cells and is also hypermethylated compared to normal plasma cells (27). On the other hand, to our knowledge, no study has shown so far that p53 could be mutated or inactivated in the 5 T33 cells. Cell cycle arrest in G2/M phase is common in tumor cell lines and has been shown previously by our team and by others on MM cells $(9,13)$ and on different types of cancer cell lines $(4,11)$. This $\mathrm{G} 2 / \mathrm{M}$ arrest sensitizes the cells to a second irradiation cycle. Even though they are less dependent than X-rays or $\gamma$-radiation, $\alpha$-particle emitters are not completely insensitive to cell cycle distribution. Indeed, it has been demonstrated that $\alpha$-irradiation of tumor cells was potentiated when cells were pretreated with chemotherapies that lead to a blockade in G2 phase $(12,28)$. These data suggest that combining such chemotherapies with $\alpha$-RIT or repeated injection of $\alpha$-RIT could enhance RIT treatment.

When we studied the cell death mechanisms resulting from ${ }^{213} \mathrm{Bi}$ irradiation, regardless of the detection method used, we observed only low levels of apoptosis, around 9\% and 5\% in 5T33 and LP-1, respectively (Figure 5). p53 status in LP-1 and 5T33 cell lines cannot be accounted for this result since both cell lines exhibited very high apoptosis during the same time frame when subjected to UV-B radiation (data not shown). A few studies have shown that tumor cells undergo apoptosis following ${ }^{213} \mathrm{Bi}$ irradiation (7-9). These studies used different irradiation protocols, diverse methods to assess cell death, and various tumor cells, which might explain the discrepancy in the results. In particular, Teiluf et al. (9) assessed apoptosis in human MM cells treated in vitro with ${ }^{213} \mathrm{Bi}$-anti-CD38 $\mathrm{mAb}$ using Western blot analysis which makes difficult to estimate the percent of cells actually undergoing apoptosis. They observed caspase- 3 activation and PARP cleavage 48-96 h after irradiation, which correlates with the time frame where we detected some apoptosis in 5T33 and LP-1 cells (Figure 5). Based on their results, we could hypothesize that those cells despite irradiation bypass the G2/M checkpoint to enter mitosis before undergoing apoptosis. This will have to be further studied.

Ionizing radiation induces different cell death mechanisms, including apoptosis, necrosis, necroptosis, mitotic catastrophe, senescence, and autophagic cell death (29-31). We followed cell death over 5 days after ${ }^{213} \mathrm{Bi}$ treatment and we observed in between 55 and 95\% mortality (Figure 5) while on the long term, clonogenic cell death reached 73.5-88.8\% depending on the MM cell line (Table 1). Therefore, other cell death mechanisms might be involved later after irradiation, such as mitotic catastrophe that can occur after several cell divisions or cell senescence that would prevent colony formation. Alternatively, preliminary data in our group showed that expression of DRAM, a gene implicated in autophagy, was increased in T cells after irradiation with ${ }^{211} \mathrm{At}$ and ${ }^{213} \mathrm{Bi}$ (unpublished data). Therefore, we performed Western blot analyses of LC3B-II form, which is correlated with the presence of autophagosomes at different time points after irradiation with ${ }^{213} \mathrm{Bi}$. Our results show an increase of LC3B-II form after irradiation, and the presence of autophagosomes characterized by a lipidic bilayer membrane was confirmed through TEM. Altogether, these data suggest that $\alpha$-emitters induce autophagy in MM cells. EBRT is known to induce autophagy (32), and few studies have shown that irradiation with high LET neutrons can also induce such mechanism $(33,34)$, but to our knowledge, no study so far had investigated the impact of $\alpha$-particle emitters on autophagy.

The implication of autophagy in cell death has been questioned, being considered either as a programmed cell death mechanism $(35,36)$ or as a stress response mechanism which can eventually lead to cell death $(37,38)$. In our study, we observed that the use of autophagy inhibitor 3-MA resulted in protecting LP-1 against ${ }^{213} \mathrm{Bi}$-induced proliferation inhibition, suggesting that autophagy is involved in tumor sensitization to irradiation and cell death induction. Moreover, it has been already shown that excess autophagy could lead to MM cell death $(39,40)$. We also observed that when clonogenic colony assays were performed on ${ }^{213} \mathrm{Bi}$-irradiated LP-1 in the presence of 3-MA, cell death occurred to the same extent than without autophagic inhibition. This suggests that autophagy is involved in cell death after ${ }^{213} \mathrm{Bi}$ irradiation, but when this mechanism is blocked, other cell death pathways are activated, for example, necrosis. However, to reinforce our data, we will have to further depict the exact mechanism of autophagy after ${ }^{213} \mathrm{Bi}$ irradiation, by confirming that 3-MA indeed acts on the amount of autophagosomes, by using other inhibitors like bafilomycin A1 that inhibits the final phase of autophagy, the autophagosome degradation, or siRNA directed against protein involved in the autophagic process, and by studying more MM cell lines. It would also be interesting to investigate how cell death occurs when autophagy is inhibited with 3-MA. In this study, we did not observe any effect of 3-MA on the 5T33 cells after irradiation. We used nevertheless the same inhibitor concentration in both MM cell lines (1.25 nM) even though they do not have the same proliferation rate. Indeed 5 T33 cells cycle faster than LP-1 cells with a doubling time around 14 versus $28 \mathrm{~h}$, respectively. This cell cycle difference between the two cell lines was also noticeable in proliferation assays where mean ${ }^{3} \mathrm{H}$-thymidine incorporation was around $90,000 \mathrm{cpm}$ for $5 \mathrm{~T} 33$ at $0 \mathrm{kBq} / \mathrm{mL}$ versus around 54,000 cpm for LP-1 (Figure 1) as well as in cell cycle assays where G2/M arrest occurred already at $6 \mathrm{~h}$ after irradiation in 5T33 and at $24 \mathrm{~h}$ in LP-1 (Figure 4). Therefore, it would be important to repeat the experiments with increasing amounts of 3-MA to ensure that we use the optimal concentration in 5 T33 cells.

The role of autophagy in cancer has also been a subject of debate. Some studies have shown that autophagy contributes to tumor cell radioresistance $(41,42)$ while others have demonstrated that autophagy participates in tumor cell radiosensitization $(43,44)$. However, a recent study has shown that if autophagy inhibition radiosensitizes tumor cells in vitro, it does 
reduce in vivo radioresponse highlighting the importance of the autophagic process in immunogenic signaling, especially through the release of ATP (45). Activation of autophagy is mandatory for ATP secretion in the extracellular medium (46) and leads to ICD (47). Extracellular ATP is a very potent chemoattractant for immune cells to ICD sites (48) and promotes DCs differentiation (49), inflammasome activation, and further proinflammatory IL- $1 \beta$ cytokine secretion (50). In this study, we observed that ${ }^{213} \mathrm{Bi}$-treated MM cells, especially LP-1 cell line, released a soluble factor capable of activating DCs, suggesting that the tumor cells underwent ICD after $\alpha$-irradiation. We recently demonstrated that ${ }^{213} \mathrm{Bi}$ was indeed able of inducing ICD in MC-38 cells resulting in Hsp70 and HMGB1 secretion in the extracellular medium and promoting a specific antitumor immune response $(20,21)$. However, when we looked at potential DAMPs in ${ }^{213} \mathrm{Bi}$-treated MM cell supernatants, we could not detect any significant release of HMGB1, Hsp70, or TNF $\alpha$ or membrane expression of Hsp70, Hsp90, or calreticulin on irradiated tumor cells. Interestingly, no DC activation was seen when irradiated culture media were subjected to freeze-thaw cycle. This loss of biological activity suggests that the activation factor is unstable but does not provide insights on its molecular nature. Therefore, it would be important to screen other proinflammatory cytokines. Alternatively, based on current literature, it would be interesting to dose ATP or ROS.

In summary, this radiobiology study shows that ${ }^{213} \mathrm{Bi}$ induces DSBs in MM cells, followed by cell proliferation arrest related to cell cycle blockade in G2 phase, finally leading to cell death. We only observed low levels of apoptosis, and necrosis seems to be the major cell death mode induced in MM cells after treatment with ${ }^{213} \mathrm{Bi}$. In addition, ${ }^{213} \mathrm{Bi}$ irradiation induces autophagy in MM cells, which could be involved in initial

\section{REFERENCES}

1. Kaminski MS, Estes J, Zasadny KR, Francis IR, Ross CW, Tuck M, et al. Radioimmunotherapy with iodine (131)I tositumomab for relapsed or refractory B-cell non-Hodgkin lymphoma: updated results and long-term follow-up of the University of Michigan experience. Blood (2000) 96:1259-66.

2. Witzig TE, Gordon LI, Cabanillas F, Czuczman MS, Emmanouilides C, Joyce $\mathrm{R}$, et al. Randomized controlled trial of yttrium-90-labeled ibritumomab tiuxetan radioimmunotherapy versus rituximab immunotherapy for patients with relapsed or refractory low-grade, follicular, or transformed B-cell non-Hodgkin's lymphoma. J Clin Oncol (2002) 20:2453-63. doi:10.1200/ JCO.2002.11.076

3. de Kruijff RM, Wolterbeek HT, Denkova AG. A critical review of alpha radionuclide therapy - how to deal with recoiling daughters? Pharmaceuticals (Basel) (2015) 8:321-36. doi:10.3390/ph8020321

4. Yong KJ, Milenic DE, Baidoo KE, BrechbielMW.(212)Pb-radioimmunotherapy induces $\mathrm{G}(2)$ cell-cycle arrest and delays DNA damage repair in tumor xenografts in a model for disseminated intraperitoneal disease. Mol Cancer Ther (2012) 11:639-48. doi:10.1158/1535-7163.MCT-11-0671

5. Kitson SL, Cuccurullo V, Moody TS, Mansi L. Radionuclide antibody-conjugates, a targeted therapy towards cancer. Curr Radiopharm (2013) 6:57-71. d oi:10.2174/1874471011306020001

6. Sgouros G, Roeske JC, McDevitt MR, Palm S, Allen BJ, Fisher DR, et al. MIRD Pamphlet No. 22 (abridged): radiobiology and dosimetry of alpha-particle emitters for targeted radionuclide therapy. J Nucl Med (2010) 51:311-28. doi:10.2967/jnumed.108.058651

7. Friesen C, Glatting G, Koop B, Schwarz K, Morgenstern A, Apostolidis C, et al. Breaking chemoresistance and radioresistance with [213Bi]anti-CD45 proliferation arrest and cell death. Finally, this study opens new prospects on $\alpha$-particle action since induction of autophagy in MM tumor cells could be an advantageous feature to activate immune cells.

\section{AUTHOR CONTRIBUTIONS}

J-BG, FD, and JG contributed to conception and design. J-BG, SG, JM, AM, FB, AF-C, YG, MC, and JG contributed to development of methodology. J-BG, SG, JM, AM, FB, AF-C, YG, and JG contributed to acquisition of data. J-BG, SG, JM, $\mathrm{AM}, \mathrm{FB}, \mathrm{AF}-\mathrm{C}, \mathrm{YG}, \mathrm{MC}, \mathrm{FD}$, and JG contributed to analysis and interpretation of data. J-BG, SG, JM, AM, FB, AF-C, YG, $\mathrm{MC}, \mathrm{FD}$, and JG contributed to writing and review of the manuscript. MC, FD, and JG contributed to study supervision.

\section{ACKNOWLEDGMENTS}

We would like to thank Paul Pilet, SC3M Plateform, for his help with TEM. We thank the Development and clinical transfer platform (CICBT0503, Nantes) as well as the Cytocell and Radioactivity platforms (SFR François Bonamy, IRS-UN, University of Nantes). We would also like to thank Marie-Hélène Gaugler for critical reading of the manuscript.

\section{FUNDING}

This work was supported by grants from La Ligue Contre le Cancer and the Pays de la Loire Council "Nucléaire pour la Santé" (Nucsan). J-BG and JM are supported by MESR grants from the French Ministry of Research and Higher Education. $\mathrm{AM}$ and $\mathrm{FB}$ are supported by the European Commission.

antibodies in leukemia cells. Cancer Res (2007) 67:1950-8. doi:10.1158/00085472.CAN-06-3569

8. Friesen C, Roscher M, Hormann I, Leib O, Marx S, Moreno J, et al. Anti-CD33-antibodies labelled with the alpha-emitter Bismuth-213 kill CD33-positive acute myeloid leukaemia cells specifically by activation of caspases and break radio- and chemoresistance by inhibition of the anti-apoptotic proteins X-linked inhibitor of apoptosis protein and B-cell lymphoma-extra large. Eur J Cancer (2013) 49:2542-54. doi:10.1016/j. ejca.2013.04.008

9. Teiluf K, Seidl C, Blechert B, Gaertner FC, Gilbertz K-P, Fernandez V, et al. $\alpha$-Radioimmunotherapy with $213 \mathrm{Bi}$-anti-CD38 immunoconjugates is effective in a mouse model of human multiple myeloma. Oncotarget (2015) 6:4692-703. doi:10.18632/oncotarget.2986

10. Seidl C, Schröck H, Seidenschwang S, Beck R, Schmid E, Abend M, et al. Cell death triggered by alpha-emitting 213Bi-immunoconjugates in HSC45-M2 gastric cancer cells is different from apoptotic cell death. Eur J Nucl Med Mol Imaging (2005) 32:274-85. doi:10.1007/s00259-004-1653-3

11. Seidl C, Port M, Gilbertz K-P, Morgenstern A, Bruchertseifer F, Schwaiger M, et al. 213Bi-induced death of HSC45-M2 gastric cancer cells is characterized by G2 arrest and up-regulation of genes known to prevent apoptosis but induce necrosis and mitotic catastrophe. Mol Cancer Ther (2007) 6:2346-59. doi:10.1158/1535-7163.MCT-07-0132

12. Supiot S, Gouard S, Charrier J, Apostolidis C, Chatal J-F, Barbet J, et al. Mechanisms of cell sensitization to alpha radioimmunotherapy by doxorubicin or paclitaxel in multiple myeloma cell lines. Clin Cancer Res (2005) 11:7047s-52s. doi:10.1158/1078-0432.CCR-1004-0021

13. Supiot S, Faivre-Chauvet A, Couturier O, Heymann MF, Robillard N, Kraeber-Bodéré F, et al. Comparison of the biologic effects of MA5 and B-B4 
monoclonal antibody labeled with iodine-131 and bismuth-213 on multiple myeloma. Cancer (2002) 94:1202-9. doi:10.1002/cncr.10286

14. Chérel M, Gouard S, Gaschet J, Saï-Maurel C, Bruchertseifer F, Morgenstern A, et al. 213Bi radioimmunotherapy with an anti-mCD138 monoclonal antibody in a murine model of multiple myeloma. J Nucl Med (2013) 54:1597-604. doi:10.2967/jnumed.112.111997

15. Gouard S, Pallardy A, Gaschet J, Faivre-Chauvet A, Bruchertseifer F, Morgenstern A, et al. Comparative analysis of multiple myeloma treatment by CD138 antigen targeting with bismuth-213 and Melphalan chemotherapy. Nucl Med Biol (2014) 41(Suppl):e30-5. doi:10.1016/j.nucmedbio.2014.02.008

16. Ménager J, Gorin J-B, Maurel C, Drujont L, Gouard S, Louvet C, et al. Combining $\alpha$-radioimmunotherapy and adoptive $\mathrm{T}$ cell therapy to potentiate tumor destruction. PLoS One (2015) 10:e0130249. doi:10.1371/journal. pone. 0130249

17. Apetoh L, Ghiringhelli F, Tesniere A, Obeid M, Ortiz C, Criollo A, et al. Toll-like receptor 4-dependent contribution of the immune system to anticancer chemotherapy and radiotherapy. Nat Med (2007) 13:1050-9. doi:10.1038/nm1622

18. Golden EB, Frances D, Pellicciotta I, Demaria S, Barcellos-Hoff MH, Formenti SC. Radiation fosters dose-dependent and chemotherapy-induced immunogenic cell death. Oncoimmunology (2014) 3:e28518. doi:10.4161/onci.28518

19. Formenti SC, Demaria S. Combining radiotherapy and cancer immunotherapy: a paradigm shift. J Natl Cancer Inst (2013) 105:256-65. doi:10.1093/jnci/djs629

20. Gorin J-B, Ménager J, Gouard S, Maurel C, Guilloux Y, Faivre-Chauvet A, et al. Antitumor immunity induced after $\alpha$ irradiation. Neoplasia (2014) 16:319-28. doi:10.1016/j.neo.2014.04.002

21. Gorin J-B, Guilloux Y, Morgenstern A, Chérel M, Davodeau F, Gaschet J. Using $\alpha$ radiation to boost cancer immunity? Oncoimmunology (2014) 3:e954925. do i: $10.4161 / 21624011.2014 .954925$

22. Keisari Y, Hochman I, Confino H, Korenstein R, Kelson I. Activation of local and systemic anti-tumor immune responses by ablation of solid tumors with intratumoral electrochemical or alpha radiation treatments. Cancer Immunol Immunother (2014) 63:1-9. doi:10.1007/s00262-013-1462-2

23. Mizushima N, Yoshimori T. How to interpret LC3 immunoblotting. Autophagy (2007) 3:542-5. doi:10.4161/auto.4600

24. Bernhard EJ, Maity A, Muschel RJ, McKenna WG. Effects of ionizing radiation on cell cycle progression. A review. Radiat Environ Biophys (1995) 34:79-83. doi:10.1007/BF01275210

25. Gadbois DM, Crissman HA, Nastasi A, Habbersett R, Wang SK, Chen $\mathrm{D}$, et al. Alterations in the progression of cells through the cell cycle after exposure to alpha particles or gamma rays. Radiat Res (1996) 146:414-24. doi:10.2307/3579303

26. Azzam EI, de Toledo SM, Waker AJ, Little JB. High and low fluences of alpha-particles induce a G1 checkpoint in human diploid fibroblasts. Cancer Res (2000) 60:2623-31.

27. Hurt EM, Thomas SB, Peng B, Farrar WL. Reversal of p53 epigenetic silencing in multiple myeloma permits apoptosis by a p53 activator. Cancer Biol Ther (2006) 5:1154-60. doi:10.4161/cbt.5.9.3001

28. Vallon M, Seidl C, Blechert B, Li Z, Gilbertz K-P, Baumgart A, et al. Enhanced efficacy of combined 213Bi-DTPA-F3 and paclitaxel therapy of peritoneal carcinomatosis is mediated by enhanced induction of apoptosis and G2/M phase arrest. Eur J Nucl Med Mol Imaging (2012) 39:1886-97. doi:10.1007/ s00259-012-2203-Z

29. Eriksson D, Stigbrand T. Radiation-induced cell death mechanisms. Tumour Biol (2010) 31:363-72. doi:10.1007/s13277-010-0042-8

30. Lauber K, Ernst A, Orth M, Herrmann M, Belka C. Dying cell clearance and its impact on the outcome of tumor radiotherapy. Front Oncol (2012) 2:116. doi:10.3389/fonc.2012.00116

31. Mirzayans R, Andrais B, Scott A, Wang YW, Murray D. Ionizing radiation-induced responses in human cells with differing TP53 status. Int J Mol Sci (2013) 14:22409-35. doi:10.3390/ijms141122409

32. Palumbo S, Comincini S. Autophagy and ionizing radiation in tumors: the "survive or not survive" dilemma. J Cell Physiol (2013) 228:1-8. doi:10.1002/ jcp. 24118

33. Altmeyer A, Ignat M, Denis J-M, Messaddeq N, Gueulette J, Mutter D, et al. Cell death after high-LET irradiation in orthotopic human hepatocellular carcinoma in vivo. In vivo (2011) 25:1-9.

34. Jin X, Liu Y, Ye F, Liu X, Furusawa Y, Wu Q, et al. Role of autophagy in high linear energy transfer radiation-induced cytotoxicity to tumor cells. Cancer Sci (2014) 105:770-8. doi:10.1111/cas.12422
35. Gozuacik D, Kimchi A. Autophagy as a cell death and tumor suppressor mechanism. Oncogene (2004) 23:2891-906. doi:10.1038/sj.onc.1207521

36. Tsujimoto Y, Shimizu S. Another way to die: autophagic programmed cell death. Cell Death Differ (2005) 12(Suppl 2):1528-34. doi:10.1038/ sj.cdd. 4401777

37. Kroemer G, Galluzzi L, Vandenabeele P, Abrams J, Alnemri ES, Baehrecke EH, et al. Classification of cell death: recommendations of the Nomenclature Committee on Cell Death 2009. Cell Death Differ (2009) 16:3-11. doi:10.1038/ cdd.2008.150

38. Galluzzi L, Vitale I, Abrams JM, Alnemri ES, Baehrecke EH, Blagosklonny MV, et al. Molecular definitions of cell death subroutines: recommendations of the Nomenclature Committee on Cell Death 2012. Cell Death Differ (2012) 19:107-20. doi:10.1038/cdd.2011.96

39. Hoang B, Benavides A, Shi Y, Frost P, Lichtenstein A. Effect of autophagy on multiple myeloma cell viability. Mol Cancer Ther (2009) 8:1974-84. doi:10.1158/1535-7163.MCT-08-1177

40. Michallet A-S, Mondiere P, Taillardet M, Leverrier Y, Genestier L, Defrance T. Compromising the unfolded protein response induces autophagy-mediated cell death in multiple myeloma cells. PLoS One (2011) 6:e25820. doi:10.1371/ journal.pone. 0025820

41. Lomonaco SL, Finniss S, Xiang C, DeCarvalho A, Umansky F, Kalkanis $\mathrm{SN}$, et al. The induction of autophagy by gamma-radiation contributes to the radioresistance of glioma stem cells. Int J Cancer (2009) 125:717-22. doi:10.1002/ijc.24402

42. Chaachouay H, Ohneseit P, Toulany M, Kehlbach R, Multhoff G, Rodemann HP. Autophagy contributes to resistance of tumor cells to ionizing radiation. Radiother Oncol (2011) 99:287-92. doi:10.1016/j.radonc.2011.06.002

43. Kim KW, Moretti L, Mitchell LR, Jung DK, Lu B. Combined Bcl-2/mammalian target of rapamycin inhibition leads to enhanced radiosensitization via induction of apoptosis and autophagy in non-small cell lung tumor xenograft model. Clin Cancer Res (2009) 15:6096-105. doi:10.1158/1078-0432. CCR-09-0589

44. Chang S-H, Minai-Tehrani A, Shin J-Y, Park S, Kim J-E, Yu K-N, et al. Beclin1-induced autophagy abrogates radioresistance of lung cancer cells by suppressing osteopontin. J Radiat Res (2012) 53:422-32. doi:10.1269/jrr.11148

45. Ko A, Kanehisa A, Martins I, Senovilla L, Chargari C, Dugue D, et al. Autophagy inhibition radiosensitizes in vitro, yet reduces radioresponses in vivo due to deficient immunogenic signalling. Cell Death Differ (2013) 21:92-9. doi:10.1038/cdd.2013.124

46. Michaud M, Martins I, Sukkurwala AQ, Adjemian S, Ma Y, Pellegatti P, et al. Autophagy-dependent anticancer immune responses induced by chemotherapeutic agents in mice. Science (2011) 334:1573-7. doi:10.1126/ science. 1208347

47. Kepp O, Senovilla L, Vitale I, Vacchelli E, Adjemian S, Agostinis P, et al. Consensus guidelines for the detection of immunogenic cell death. Oncoimmunology (2014) 3:e955691. doi:10.4161/21624011.2014.955691

48. Elliott MR, Chekeni FB, Trampont PC, Lazarowski ER, Kadl A, Walk SF, et al. Nucleotides released by apoptotic cells act as a find-me signal to promote phagocytic clearance. Nature (2009) 461:282-6. doi:10.1038/nature08296

49. Ma Y, Adjemian S, Mattarollo SR, Yamazaki T, Aymeric L, Yang H, et al. Anticancer chemotherapy-induced intratumoral recruitment and differentiation of antigen-presenting cells. Immunity (2013) 38:729-41. doi:10.1016/j. immuni.2013.03.003

50. Ghiringhelli F, Apetoh L, Tesniere A, Aymeric L, Ma Y, Ortiz C, et al. Activation of the NLRP3 inflammasome in dendritic cells induces IL-1beta-dependent adaptive immunity against tumors. Nat Med (2009) 15:1170-8. doi:10.1038/ nm.2028

Conflict of Interest Statement: The authors declare that the research was conducted in the absence of any commercial or financial relationships that could be construed as a potential conflict of interest.

Copyright () 2015 Gorin, Gouard, Ménager, Morgenstern, Bruchertseifer, FaivreChauvet, Guilloux, Chérel, Davodeau and Gaschet. This is an open-access article distributed under the terms of the Creative Commons Attribution License (CC BY). The use, distribution or reproduction in other forums is permitted, provided the original author(s) or licensor are credited and that the original publication in this journal is cited, in accordance with accepted academic practice. No use, distribution or reproduction is permitted which does not comply with these terms. 